\title{
Does cystic fibrosis constitute an advantage in COVID-19 infection?
}

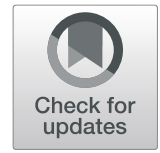

Valentino Bezzerri, Francesca Lucca, Sonia Volpi and Marco Cipolli ${ }^{*}$ (D)

\begin{abstract}
The Veneto region is one of the most affected Italian regions by COVID-19. Chronic lung diseases, such as chronic obstructive pulmonary disease (COPD), may constitute a risk factor in COVID-19. Moreover, respiratory viruses were generally associated with severe pulmonary impairment in cystic fibrosis (CF). We would have therefore expected numerous cases of severe COVID-19 among the CF population. Surprisingly, we found that CF patients were significantly protected against infection by SARS-CoV-2. We discussed this aspect formulating some reasonable theories.
\end{abstract}

Keywords: Cystic fibrosis, SARS-CoV-2, Covid-19, Azythromycin, DNase

\section{Introduction}

The comorbidities of obesity, hypertension, diabetes, heart failure, and chronic lung disease have been associated with poor outcome in coronavirus disease 2019 (COVID-19) [1]. Once Severe Acute Respiratory Syndrome (SARS) - Coronavirus ( $\mathrm{CoV})-2$ has infected host cells, excessive inflammatory and thrombotic processes take place. A cytokine storm release with markedly elevated IL-6 levels are associated with increased lethality [2]. Increased neutrophilia is part of that inflammatory response and has been associated with a poorer outcome. Increased neutrophil extracellular traps (NET) have been hypothesized to be predictive of poor outcome in COVID-19 patients [3].

Cystic fibrosis (CF) lung disease, characterized by the release of a many proinflammatory cytokines and chemokines, is the major cause of morbidity and mortality in CF. Excessive NET accumulation has been observed in the CF airway [4]. Moreover, influenza and other respiratory viral infections are known to cause severe pulmonary impairment in CF. [5] Because of the risk factors of chronic lung disease and host hyper-immune

\footnotetext{
* Correspondence: marco.cipolli@aovr.veneto.it

Cystic Fibrosis Center of Verona, Azienda Ospedaliera Universitaria Integrata, 37126 Verona, Italy
}

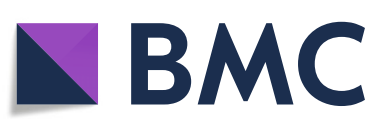

(c) The Author(s). 2020 Open Access This article is licensed under a Creative Commons Attribution 4.0 International License, which permits use, sharing, adaptation, distribution and reproduction in any medium or format, as long as you give appropriate credit to the original author(s) and the source, provide a link to the Creative Commons licence, and indicate if changes were made. The images or other third party material in this article are included in the article's Creative Commons licence, unless indicated otherwise in a credit line to the material. If material is not included in the article's Creative Commons licence and your intended use is not permitted by statutory regulation or exceeds the permitted use, you will need to obtain permission directly from the copyright holder. To view a copy of this licence, visit http://creativecommons.org/licenses/by/4.0/ The Creative Commons Public Domain Dedication waiver (http://creativecommons.org/publicdomain/zero/1.0/) applies to the data made available in this article, unless otherwise stated in a credit line to the data. status, one would surmise that CF patients would be at an increased risk of developing severe COVID-19 illness.

\section{Methods}

We conducted a retrospective study of $532 \mathrm{CF}$ patients followed at the Cystic Fibrosis Center of Verona, Italy. SARS-CoV-2 positivity was tested by collecting combined nose-throat swabs and subsequent Real-Time PCR using the Nimbus MuDT tm (Seegene, Seoul, South Korea), and Simplexa COVID-19 Direct kits (DiaSorin, Stillwater, MN, USA), following the manufacturer guidelines. All patients tested in this study reported symptoms consistent with respiratory infection and were hospital-

\section{Results}

The Veneto region is one of the Italian regions most strongly affected by COVID-19, with 19,729 cases and 2062 related fatalities (as of 23 July 2020). The Veneto region health system has carried out 1,149,084 multiple COVID-19 tests on 465,433 subjects so far (data from

From 1 April to 23 July 2020, we contacted all the 532 patients from Veneto, of whom 118 subjects (22.2\%), with a median age of 32.4 years (range $0.12-65.3$ years), the Italian Ministry of Health). 
Table 1 Demographic and Epidemiologic Data from the Veneto Region

\begin{tabular}{lllllll}
\hline Condition & Population & $\begin{array}{l}\text { Mean } \\
\text { (years) }\end{array}$ & $\begin{array}{l}\text { Tested subjects (\% of regional } \\
\text { population) }\end{array}$ & $\begin{array}{l}\text { COVID-19 } \\
\text { cases }\end{array}$ & $\begin{array}{l}\text { Rate of infection (\% of regional } \\
\text { population) }\end{array}$ & $\begin{array}{l}\text { COVID-19 } \\
\text { fatalities }\end{array}$ \\
\hline $\begin{array}{l}\text { General } \\
\text { population }\end{array}$ & $4,907,704^{\mathrm{a}}$ & 45,4 & $465,433(9.5 \%)$ & 19,729 & $0.40 \%$ & 2062 \\
$\begin{array}{l}\text { CF } \\
\text { population }\end{array}$ & 532 & 27,5 & $118(22.2 \%)$ & 1 & $0.19 \%$ & $10.4 \%$ \\
\hline
\end{tabular}

CFR case fatality rate

${ }^{\text {a }}$ Data from the Istituto Nazionale di Statistica (ISTAT) of Italy, updated to 1 January 2020

undergone further combined nose and throat swab test for SARS-CoV-2. Surprisingly, we found that CF patients were significantly protected against infection by SARSCoV-2. We identified only one CF patient, a 46-year-old man, who underwent lung transplantation in 2011, with COVID-19 infection. Prior to COVID-19 positivity, this patient exhibited a preserved lung function (mean ppFEV1 in the last 12 months 90.4\%), MS-Staphylococcus aureus and Pseudomonas aeruginosa colonization of the airways, chronic kidney disease, impaired nutritional status (BMI $17.7 \mathrm{~kg} / \mathrm{m}^{2}$ ). Upon SARS-CoV-2 infection, the patient reported only mild symptoms including dry cough and body temperature, and he did not require intensive care unit (ICU) admission. These data indicate that the COVID-19 infection rate in the Veneto regional CF population is $0.19 \%$, in contrast to $0.40 \%$ in the general population (Table 1).

\section{Discussion}

CF condition is supposed to represent a comorbidity for COVID-19. Our data show instead that the prevalence of COVID-19 in CF population of one of the Italian region most affected by the SARS-CoV-2 outbreak, namely Veneto region, is reduced compared with general population. Interestingly, our data are in line with emerging evidence observed by the "COVID-CF project in Europe" of the European Cystic Fibrosis Society (https://www. ecfs.eu/covid-cf-project-europe). According to preliminary data from this project, among approximately 48,000 European CF patients, eight patients needed ICU admission and only three died for COVID-19 (CFR 3.2\%) (as of 15 July 2020).

Several factors might play a role in reducing the prevalence and, perhaps, the lethality of COVID-19: typical behavior in patients with $\mathrm{CF}$, who might wear protective masks and avoid contact with sick people, use of antibiotics, or host factors. A more mild form of COVID-19 might be expected because disruption of IL-6 signaling in CF lungs occurs through elevated serine protease release and subsequent cleavage of both membrane-bound and soluble IL-6 receptors [6]. Chronic pharmacological therapies, including azithromycin (immunomodulator) and DNase (mucolytic), administered to 56 and $51 \%$ of our patients, respectively, might also contribute to the protection. Vitamin
$\mathrm{D}$ deficiency is a common feature of CF condition. The result is that CF patients generally undergo vitamin $\mathrm{D}$ supplementation, which may have a protective effect against COVID-19. However, it has been reported that the levels of vitamin D in CF patients remain lower than normal even after supplementation [7].

All together, these data strengthen the hypothesis that CF may constitute an advantage in COVID-19, encouraging the scientific community to look for the possible reasons behind this unexpected scenario.

\section{Abbreviations}

CF: Cystic Fibrosis; ICU: intensive care unit; SARS-CoV-2: Severe Acute Respiratory Syndrome-Coronavirus-2; COVID-19: Coronavirus disease 2019; NET: Neutrophil extracellular trap

\section{Acknowledgements}

The authors thank Dr. Seth J Corey (Cleveland Clinic, OH, USA) for the useful suggestions and comments on this work and for his linguistic assistance.

\section{Authors' contributions}

VB interpreted the data and drafted the manuscript; FL, SV and MC collected and reviewed clinical data; MC conceived the idea and critically reviewed the manuscript. All the authors read and approved the final manuscript.

\section{Funding}

Not applicable.

\section{Availability of data and materials}

Data were obtained from the Institutional Database at Azienda Ospedaliera Universitaria Integrata, Verona.

\section{Ethics approval and consent to participate}

This preliminary study reported only a retrospective analysis of data available through the Institutional Database. Personal data were restricted to essential information, and were treated in order to guarantee the respect of privacy of the involved patients, as specifically stated by Italian Law D.Lgs n.196 of 2003 about personal data protection. Therefore, the study did not require preliminary evaluation by the local Ethical Committee.

\section{Consent for publication \\ Not applicable.}

\section{Competing interests}

The authors declare that they have no competing interests.

Received: 24 July 2020 Accepted: 25 September 2020

Published online: 06 October 2020

References

1. Remuzzi A, Remuzzi G. COVID-19 and Italy: what next? Lancet. 2020; 395(10231):1225-8.

2. Zhou F, Yu T, Du R, et al. Clinical course and risk factors for mortality of adult inpatients with COVID-19 in Wuhan, China: a retrospective cohort study. Lancet. 2020;395(10229):1054-62. 
3. Barnes BJ, Adrover JM, Baxter-Stoltzfus A, et al. Targeting potential drivers of COVID-19: neutrophil extracellular traps. J Exp Med. 2020;217(6):e20200652.

4. Dwyer M, Shan Q, D'Ortona S, et al. Cystic fibrosis sputum DNA has NETosis characteristics and neutrophil extracellular trap release is regulated by macrophage migration-inhibitory factor. J Innate Immun. 2014;6(6):765-79.

5. Viviani L, Assael BM, Kerem E. Group EAHNs. Impact of the a (H1N1) pandemic influenza (season 2009-2010) on patients with cystic fibrosis. J Cyst Fibros. 2011;10(5):370-6.

6. McGreal EP, Davies PL, Powell W, et al. Inactivation of IL-6 and soluble IL-6 receptor by neutrophil derived serine proteases in cystic fibrosis. BiochimBiophys Acta. 2010;1802(7-8):649-58.

7. Rovner AJ, Stallings VA, Schall Jl, Leonard MB, Zemel BS. Vitamin D insufficiency in children, adolescents, and young adults with cystic fibrosis despite routine oral supplementation. Am J Clin Nutr. 2007;86:1694-9.

\section{Publisher's Note}

Springer Nature remains neutral with regard to jurisdictional claims in published maps and institutional affiliations.

Ready to submit your research? Choose BMC and benefit from:

- fast, convenient online submission

- thorough peer review by experienced researchers in your field

- rapid publication on acceptance

- support for research data, including large and complex data types

- gold Open Access which fosters wider collaboration and increased citations

- maximum visibility for your research: over $100 \mathrm{M}$ website views per year

At BMC, research is always in progress.

Learn more biomedcentral.com/submissions 